\title{
The Tall Poppy Syndrome in Orthopedics and Medicine
}

\author{
Douglas E Garland* \\ Clinical Professor of Orthopedic Surgery, University of Southern California, Los Angeles, California, USA
}

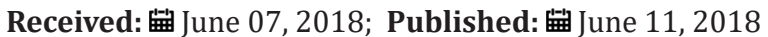

*Corresponding author: Douglas E Garland, Clinical Professor of Orthopedic Surgery, University of Southern California, Los Angeles, California, USA

\section{Opinion}

The Tall Poppy Syndrome (TPS) is a metaphor which symbolizes viewing a poppy field and noticing one poppy towering above the others; a penchant by an individual, group or society exists to cut down this tall poppy so that all are equal and uniform. A "tall poppy" is defined as someone with fame, fortune, achievements or skills. The syndrome has been identified in many countries with their own metaphors or phrases since antiquity. The entity is relatively unrecognized in the United States perhaps because of the constitutional rights of the individual and capitalism which is based on meritocracy. Lack of recognition does not negate existence. Daily examples may be found in the industries of sport, business, entertainment and especially politics. TPS may be noted in medicine since antiquity as well. Nearly every new discovery, technique, or rivalry is a breeding ground for TPS. One of medicine's greatest rivalries occurred between Louis Pasteur (France) and Robert Koch (Germany) regarding the germ theory of disease. Their rivalry leads to denigrating each other privately, and at meetings which would also draw in other doctors often with a dose of nationalism for good measure. Envy was described as an early root of TPS especially in people with low self esteem [1]. The envier lacked what the tall poppy possessed and had the option to improve (good envy) or denigrate or cut down the tall poppy (bad envy). Further psychosocial studies have extended behaviors to include deservingness and resentment as well as others [2].

Deservingness involves value judgments by the cutter about the outcomes of the person to be cut down or "tall poppied"; the persons got what they deserved. Resentment is indignation about unfair treatment; cutting the person down could end in revenge. A recently published career summary of an orthopedic surgeon could also be interpreted as an example of TPS [3]. The young orthopedist entered practice when arthroscopy and the specialty of sports medicine were at their infancy. His surgical techniques were disparaged by his orthopedic colleagues. Membership in the state orthopedic association and other orthopedic organizations were originally denied as were many of scientific papers. As he and the surgical techniques became accepted, so did memberships and publications. As medicine moves to a business model with more physician employment, the hierarchy and promotion will become a new source of TPS. Advancement may not always be based on merit. Specific needs, "pull", and persons with new social-justice identity politics may prevent the high achiever's advancement causing the high achiever to be cut down to justify the elevation of the others or forcing the high achiever to do some cutting. The White House Doctor manages a staff of five physicians who provide medical care for all things White House which includes being the President's physician. Dr. Lonny L. Johnson, President Trump's private doctor, wrangled with Dr. Jeffry Kuhlman, Johnson's boss, for control of the White House office. To settle the dispute the Navy's inspector general services were required which issued a report in 2012. This rivalry forced people to choose sides. When President Trump nominated Dr. Johnson to lead the Veterans Affairs Department, accusations, mostly unfounded, emerged forcing Dr. Johnson to withdraw his name from consideration.

The treatment of any disease begins with defining the disease state, further elucidating studies and recommended treatments. TPS is well defined in most English speaking countries, except the United States, especially in Australia. Treatment involves emotional intelligence. The tall poppy may become conspicuous for some egregious reason which requires behavioral identification and modification. The cutter also must evaluate the basis for proper behavior or judgments versus improper behavior. Behaviors often become so ingrained that outside assistance is necessary to identify and treat them.

\section{References}

1. Feather N (1989) Attitudes towards the High Achiever: The Fall of the Tall Poppy. Australian J Psych 41(3): 239-267.

2 Feather N (2008) Effects of Observer's Own Status on Reactions to a High Achiever's Failure: Deservingness, Resentment, Schadenfreude, and Sympathy. Australian JPsych 60(10): 31-43.

3. Johnson L (2018) What's important: Making a Difference May Include Being Different. JBone Joint Surg Am 100(5): 443-444. 
This work is licensed under Creative Commons Attribution 4.0 License

To Submit Your Article Click Here:

Submit Article

DOI: 10.32474/OSMOAJ.2018.01.000114

$\begin{gathered}\text { Orthopedics and Sports Medicine } \\ \text { Open Access Journal }\end{gathered}$
Assets of Publishing with us
- Global archiving of articles
- Immediate, unrestricted online access
- Rigorous Peer Review Process
- Authors Retain Copyrights
- Unique DOI for all articles

